\title{
Impulsive Supply of Volatile-Rich Magmas in the Shallow Plumbing System of Mt. Etna Volcano
}

\author{
Cristina Perinelli ${ }^{1, *(\mathbb{D}}$, Silvio Mollo ${ }^{1,2}{ }^{,}$, Mario Gaeta ${ }^{1}$, Serena Pia De Cristofaro ${ }^{3}{ }^{(\mathbb{D}}$, \\ Danilo Mauro Palladino ${ }^{1}$ and Piergiorgio Scarlato ${ }^{2}$ (D) \\ 1 Dipartimento di Scienze della Terra, Sapienza-Università di Roma, P.le Aldo Moro 5, 00185 Roma, Italy; \\ silvio.mollo@uniroma1.it (S.M.); mario.gaeta@uniroma1.it (M.G.); danilo.palladino@uniroma1.it (D.M.P.) \\ 2 Istituto Nazionale di Geofisica e Vulcanologia, Via di Vigna Murata 605, 00143 Roma, Italy; \\ piergiorgio.scarlato@ingv.it \\ 3 Dipartimento di Scienze della Terra, Università degli Studi di Torino, Via Valperga Caluso 35, 10125 Torino, \\ Italy; serenapia.decristofaro@unito.it \\ * Correspondence: cristina.perinelli@uniroma1.it; Tel.: +39-06-49914916
}

Received: 18 September 2018; Accepted: 22 October 2018; Published: 25 October 2018

check for updates

\begin{abstract}
Magma dynamics at Mt. Etna volcano are frequently recognized as the result of complex crystallization regimes that, at shallow crustal levels, unexpectedly change from $\mathrm{H}_{2} \mathrm{O}$-undersaturated to $\mathrm{H}_{2} \mathrm{O}$-saturated conditions, due to the impulsive and irregular arrival of volatile-rich magmas from mantle depths. On this basis, we have performed hydrous crystallization experiments for a quantitative understanding of the role of $\mathrm{H}_{2} \mathrm{O}$ in the differentiation of deep-seated trachybasaltic magmas at the key pressure of the Moho transition zone. For $\mathrm{H}_{2} \mathrm{O}=2.1-3.2 \mathrm{wt} \%$, the original trachybasaltic composition shifts towards phonotephritic magmas never erupted during the entire volcanic activity of Mt. Etna. Conversely, for $\mathrm{H}_{2} \mathrm{O}=3.8-8.2 \mathrm{wt} \%$, the obtained trachybasalts and basaltic trachyandesites reproduce most of the pre-historic and historic eruptions. The comparison with previous low pressure experimental data and natural compositions from Mt. Etna provides explanation for (1) the abundant release of $\mathrm{H}_{2} \mathrm{O}$ throughout the plumbing system of the volcano during impulsive ascent of deep-seated magmas; (2) the upward acceleration of magmas feeding gas-dominated, sustained explosive eruptions; (3) the physicochemical changes of gas-fluxed magmas ponding at shallow crustal levels; and (4) the huge gas emissions measured at the summit craters and flank vents which result in a persistent volcanic gas plume.
\end{abstract}

Keywords: Mt. Etna; high-pressure experiments; magma ascent; $\mathrm{H}_{2} \mathrm{O}$ release

\section{Introduction}

The plumbing system of Mt. Etna volcano (Sicily, Italy) has a multifaceted geometry, variable in space and time and consisting of storage zones at different depths, where more or less primitive magmas containing variable $\mathrm{H}_{2} \mathrm{O}$ contents undergo degassing, fractional crystallization and mixing processes (cf. [1]). For example, the explosive activity of the volcano is ascribed to the impulsive upward migration of gas-rich magmas and/or fluxes of abundant volatiles from the depths [2-4]. Evidence of pulsating volatile flushing is also provided by the great volume of gases released from the summit craters and flanks of the volcano that clashes with the relatively small amount of erupted products [5]. The release of volatiles has drastic effects on the rheology of Etnean magmas and, consequently, the internal dynamics of the volcano [6]. Moreover, the large quantities of gas released may change the geochemical and isotopic compositions of near-liquidus lavas erupted at the vents and flowing onto the surface [7]. 
In this scenario, the vertically developed plumbing system represents a pathway for volatiles migration as supercritical fluids $[4,8,9]$. The impulse migration of volatiles through magmas stored beneath (or within) the volcanic edifice changes the physicochemical state of the system from $\mathrm{H}_{2} \mathrm{O}$-undersaturated to $\mathrm{H}_{2} \mathrm{O}$-saturated, with implications for mineral and melt compositions, degree of crystallization, magma ascent velocity and style of eruption [1,3,4,8,10-13].

Relevant insights into the highly variable volatile concentrations of magmas $\left(\mathrm{H}_{2} \mathrm{O}=0.5-3.5 \mathrm{wt} \%\right.$ and $\mathrm{CO}_{2}=0.02-0.25 \mathrm{wt} \%$ ) have been provided by data on melt inclusions entrapped at both shallow and moderate pressures (25-400 MPa) [14]. Within this pressure range, the differentiation process of Etnean liquids upon the effect of variable $\mathrm{H}_{2} \mathrm{O}$ concentrations have been explored through hydrous crystallization experiments [13,15-17]. However, few data are available in the literature at the key pressure of the Moho transition zone ( $\sim 800 \mathrm{MPa}$ or $\sim 24 \mathrm{~km}$ b.s.l.; [18]) at which the solubility of $\mathrm{H}_{2} \mathrm{O}$ may be very high (>10 wt \%; $[19,20]$ and references therein), thus remarkably influencing the early crystallization of gas-rich trachybasaltic magmas erupted at Mt. Etna [12,21].

In this study, we present hydrous crystallization experiments conducted at $800 \mathrm{MPa}, 1020-1200{ }^{\circ} \mathrm{C}$, 2.1-10 wt $\% \mathrm{H}_{2} \mathrm{O}$, and $\mathrm{NNO}$ buffer with the aim of better understanding the role of $\mathrm{H}_{2} \mathrm{O}$ in the differentiation of deep-seated trachybasaltic magmas. Considering the crystallization temperatures at the Moho depth recorded by clinopyroxene phenocrysts from lava fountains and lava flows, the results of our experiments show that the irregular arrival of deep-seated, volatile-rich magmas into the uppermost portions of the plumbing system may release a huge amount of $\mathrm{H}_{2} \mathrm{O}$ with remarkable implications for the dynamics of $\mathrm{H}_{2} \mathrm{O}$-undersaturated magmas ponding at shallow crustal levels.

\section{Starting Materials and Methods}

The starting materials used in this study are two trachybasalts (i.e., HE and ME hawaiitic products) from Mt. Etna showing virtually identical compositions: on anhydrous basis, $\mathrm{HE}$ and ME have 47.78 and $48.27 \mathrm{wt} \% \mathrm{SiO}_{2}$, and 5.87 and $5.79 \mathrm{wt} \% \mathrm{Na}_{2} \mathrm{O}+\mathrm{K}_{2} \mathrm{O}$, respectively (Table 1). HE is a lava flow erupted from the western flank of the Valle del Bove during the 1991-1993 effusive activity [22]. ME is a lava flow erupted from the South-East Crater during the 2011-2013 paroxysmal activity comprising both Strombolian explosions and lava effusions $[23,24]$. These two compositions are, indeed, the most representative of the recent activity at Mt. Etna volcano.

Table 1. Composition of HE and ME starting materials. SD is the standard deviation.

\begin{tabular}{|c|c|c|c|c|}
\hline \#Oxide & HE & SD (5) & ME & SD (5) \\
\hline \multicolumn{5}{|c|}{ Experimental melt compositions } \\
\hline $\mathrm{SiO}_{2}$ & 47.78 & 0.39 & 48.27 & 0.43 \\
\hline $\mathrm{TiO}_{2}$ & 1.72 & 0.02 & 1.69 & 0.03 \\
\hline $\mathrm{Al}_{2} \mathrm{O}_{3}$ & 17.10 & 0.19 & 17.32 & 0.16 \\
\hline $\mathrm{FeO}_{\text {tot }}$ & 10.18 & 0.12 & 11.07 & 0.11 \\
\hline $\mathrm{MnO}$ & 0.17 & 0.01 & 0.17 & 0.03 \\
\hline $\mathrm{MgO}$ & 5.55 & 0.07 & 4.94 & 0.09 \\
\hline $\mathrm{CaO}$ & 10.40 & 0.12 & 9.94 & 0.10 \\
\hline $\mathrm{Na}_{2} \mathrm{O}$ & 3.84 & 0.05 & 3.73 & 0.07 \\
\hline $\mathrm{K}_{2} \mathrm{O}$ & 2.03 & 0.03 & 2.06 & 0.05 \\
\hline $\mathrm{P}_{2} \mathrm{O}_{5}$ & 0.55 & 0.01 & 0.57 & 0.03 \\
\hline Tot & 99.32 & & 99.76 & \\
\hline
\end{tabular}

Both experiments and analyses were conducted at the Department of Earth Sciences, Sapienza-University of Rome, Italy. The starting glass was produced by melting the powdered sample at $1350{ }^{\circ} \mathrm{C}$ and atmospheric pressure for $1 \mathrm{~h}$. Some glass chips were then analyzed by scanning electron microscopy, and no crystalline phases were detected. Phase equilibrium crystallization experiments were performed at $800 \mathrm{MPa}$ in a half-inch, end-loaded piston cylinder apparatus. The starting material, composed of the powdered glass and deionized $\mathrm{H}_{2} \mathrm{O}$, was loaded into a $\mathrm{Au}_{75} \mathrm{Pd}_{25}$ capsule. Variable 
amounts of $\mathrm{H}_{2} \mathrm{O}$ were added to the charges in order to obtain melt- $\mathrm{H}_{2} \mathrm{O}$ concentrations in the range between 2.1 and $10 \mathrm{wt} \%$ (Table 2), as determined by the "difference from 100" method (i.e., based on the difference to $100 \%$ of the total obtained by microprobe analyses of glasses, with accuracy of $\sim 0.5 \mathrm{wt} \% \mathrm{H}_{2} \mathrm{O}$; [25].

According to $\mathrm{H}_{2} \mathrm{O}$ solubility data ([19] see discussion below) and the absence of gas bubbles into the quenched charges, the experiments were $\mathrm{H}_{2} \mathrm{O}$-undersaturated, thus reproducing the crystallization conditions observed for Etnean magmas residing at depth [26]. The assembly consisted of fluorite-graphite-magnesia. The charge was heated directly to the target temperature (i.e., between 1020 and $1200^{\circ} \mathrm{C}$ ) that was kept constant for $8 \mathrm{~h}$ (Table 2). The temperature was controlled by a factory calibrated thermocouple $\left(\mathrm{W}_{95} \mathrm{Re}_{5}-\mathrm{W}_{74} \mathrm{Re}_{26}\right.$; type D) with accuracy of $\pm 3{ }^{\circ} \mathrm{C}$. The experiment was quenched through a cooling rate of approximately $150{ }^{\circ} \mathrm{C} / \mathrm{s}$ and then the run product was mounted in an epoxy disk to expose a polished surface.

All the runs were self-buffered; we attempted to estimate $f \mathrm{O}_{2}$ through the equation of [27] using the liquid $\mathrm{Fe}^{3+} / \mathrm{Fe}_{\text {tot }}$ mole ratios from olivine-melt $\mathrm{Fe}-\mathrm{Mg}$ exchange calculated according to [28]. This procedure yielded $f \mathrm{O}_{2}$ values of -0.3 to $+0.7 \mathrm{NNO}$, in agreement with those estimated for similar furnace assemblages $[29,30]$.

The chemical analyses were performed at the CNR-Istituto di Geologia Ambientale e Geoingegneria (Rome, Italy) using a Cameca SX50 electron microprobe (CAMECA, Gennevilliers, France) equipped with five wavelength-dispersive spectrometers using $15 \mathrm{kV}$ accelerating voltage, $15 \mathrm{nA}$ beam current for minerals and $2 \mathrm{nA}$ for glass to obviate the alkali loss during the analyses, particularly for hydrous glasses. Moreover, sodium and potassium were analyzed first to prevent alkali migration effects. The beam diameter was of $10 \mu \mathrm{m}$, and the counting time was $20 \mathrm{~s}$. The following standards were used: wollastonite ( $\mathrm{Si}$ and $\mathrm{Ca})$, corundum $(\mathrm{Al})$, diopside $(\mathrm{Mg})$, andradite $(\mathrm{Fe})$, rutile $(\mathrm{Ti})$, orthoclase $(\mathrm{K})$, jadeite $(\mathrm{Na})$, apatite $(\mathrm{P})$ and metal $(\mathrm{Mn})$. 
Table 2. Experimental conditions, mass balance calculations, and tests for equilibrium crystallization conditions.

\begin{tabular}{|c|c|c|c|c|c|c|c|c|c|c|c|c|c|}
\hline Run & $T$ & $t$ & $\mathrm{H}_{2} \mathrm{O}$ & G1 & Cpx & $\mathrm{Plg}$ & Timt & $\mathrm{Ol}$ & $\Sigma r^{2}$ & cpx-melt $K d_{\text {Fe-Mg }}$ & $\Delta$ DiHd & ${\text { plg-melt } K d_{A b-A n}}$ & ${\text { ol-melt } K d_{F e-M g}}$ \\
\hline (\#) & $\left({ }^{\circ} \mathrm{C}\right)$ & (h) & $(w t \%)$ & & & -vol \%) & & & & (Putirka et al., 2008) & (Mollo et al., 2013b) & (Putirka et al., 2008) & $\begin{array}{c}\text { Roeder and Emslie } \\
\text { (1970) }\end{array}$ \\
\hline HE-1 & 1200 & 8 & 2.7 & $100-100$ & - & - & - & - & 0.01 & - & & - & - \\
\hline HE-2 & 1125 & 8 & 2.1 & $59-57$ & $23-24$ & $15-16$ & $2-2$ & $1-1$ & 0.25 & 0.26 & 0.03 & 0.14 & 0.42 \\
\hline HE-3 & 1050 & 8 & 8.2 & $85-87$ & $9-8$ & - & $6-5$ & - & 0.19 & 0.27 & 0.05 & - & - \\
\hline HE-4 & 1020 & 8 & 10 & $100-100$ & - & - & - & - & 0.01 & - & - & - & - \\
\hline ME-1 & 1175 & 8 & 3.2 & $87-88$ & $6-5$ & $6-6$ & $1-1$ & - & 0.32 & 0.27 & 0.02 & 0.21 & - \\
\hline ME-2 & 1150 & 8 & 2.3 & $64-67$ & $11-10$ & $18-16$ & $4-4$ & $3-3$ & 0.19 & 0.27 & 0.04 & 0.18 & 0.35 \\
\hline ME-3 & 1150 & 8 & 6.2 & $100-100$ & - & - & - & - & 0.01 & 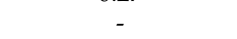 & . & - & - \\
\hline ME-4 & 1125 & 8 & 2.4 & $69-73$ & $13-12$ & $15-14$ & $1-1$ & $2-2$ & 0.21 & 0.27 & 0.08 & 0.14 & 0.54 \\
\hline ME-5 & 1090 & 8 & 4.1 & $48-53$ & $17-15$ & $26-24$ & $5-4$ & $4-4$ & 0.31 & 0.27 & 0.04 & 0.17 & 0.26 \\
\hline ME-6 & 1070 & 8 & 3.8 & $48-53$ & $18-16$ & $28-26$ & $1-1$ & $5-4$ & 0.26 & 0.27 & 0.01 & 0.15 & 0.49 \\
\hline ME-7 & 1065 & 8 & 5.0 & $56-60$ & $11-10$ & $24-22$ & $6-5$ & $3-3$ & 0.24 & 0.27 & 0.07 & 0.14 & 0.55 \\
\hline
\end{tabular}




\section{Results}

\subsection{Phase Relations}

Modal phase proportions (wt \%) were derived by mass balance calculations [31], yielding acceptable residual sum of squares $\left(\Sigma r^{2}<0.32\right.$; see Table 2$)$. For a better comparison of these estimates with vol \% data from lava flows, the volume proportions were recalculated using average densities of olivine $\left(3.3 \mathrm{~g} / \mathrm{cm}^{3}\right)$ clinopyroxene $\left(3.4 \mathrm{~g} / \mathrm{cm}^{3}\right)$, plagioclase $\left(2.6 \mathrm{~g} / \mathrm{cm}^{3}\right)$, titanomagnetite $\left(5.1 \mathrm{~g} / \mathrm{cm}^{3}\right)$ and melt (2.6-2.7 g/ $\mathrm{cm}^{3}$ from the model of [32]). According to [17], both wt \% and vol \% estimates provided almost identical values (Table 2).

Figure 1 shows that the phase assemblage is characterized by the ubiquitous occurrence of clinopyroxene and titanomagnetite at near-liquidus conditions, followed by the crystallization of plagioclase and olivine at lower temperatures and/or $\mathrm{H}_{2} \mathrm{O}$ contents. In highly crystallized charges, plagioclase is the most abundant mineral phase but its stability field progressively decreases with increasing $\mathrm{H}_{2} \mathrm{O}$. The crystallization of clinopyroxene and plagioclase increases by 50 vol \% with decreasing temperature (Table 2). In particular, the plagioclase/clinopyroxene ratio is $0.7-1.2$ at $T \geq 1125^{\circ} \mathrm{C}$, but abruptly increases to $1.5-2.2$ at $T \leq 1090{ }^{\circ} \mathrm{C}$ due to the predominant crystallization of plagioclase (Table 2). It is interesting to note that olivine crystallization occurs only at $T \leq 1150{ }^{\circ} \mathrm{C}$ and is subordinated to that of other mineral phases.

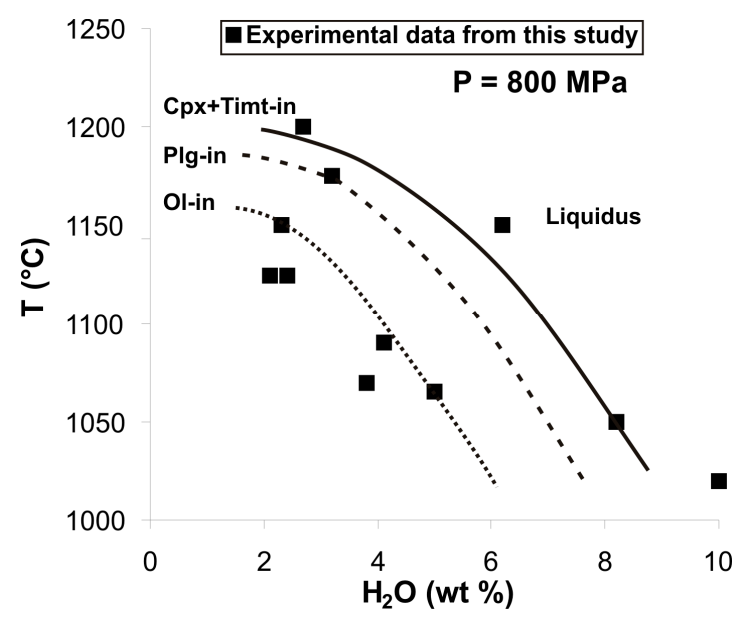

Figure 1. Temperature vs. $\mathrm{H}_{2} \mathrm{O}$ diagram showing the stability of mineral phases in our experimental charges. As the temperature decreases, the near-liquidus surface is gained by increasing amounts of $\mathrm{H}_{2} \mathrm{O}$ that lower the degree of crystallization and buffer the melt composition to trachybasalt. Cpx, clinopyroxene. Timt, titanomagnetite. Plg, plagioclase. Ol, olivine.

\subsection{Phase Compositions}

Major element concentrations of both experimental glasses and minerals are reported in Table 3. In the total alkali versus silica diagram (Figure 2), the original trachybasaltic melt obtained at $\mathrm{H}_{2} \mathrm{O}$ $=2.1-3.2 \mathrm{wt} \%$ evolves towards basaltic trachyandesitic and phonotephritic compositions, as well as the $\mathrm{Mg}$-number (i.e., $\mathrm{Mg \#}=$ atomic $\left.\mathrm{Mg} /\left(\mathrm{Mg}+\mathrm{Fe}^{2+}\right) \times 100\right)$ decreases from $\mathrm{Mg \#}_{42}$ to $\mathrm{Mg \#} 37 . \mathrm{At}_{2} \mathrm{O}$ $=3.8-8.2 \mathrm{wt} \%$, the starting melt differentiates from basaltic trachyandesite to trachyandesite to tephriphonolite with $\mathrm{Mg \#} 33-43$. The residual melts show a significant increase of $\mathrm{SiO}_{2}$ content (from 48.89 to $53.39 \mathrm{wt} \%$ ) associated with a narrow increase of alkali (from 6.49 to $9.57 \mathrm{wt} \%$ ) that, in turn, is weakly observed at $\mathrm{H}_{2} \mathrm{O}=2.1-3.2 \mathrm{wt} \%$ (Figure 2). 
Table 3. Experimental compositions of residual melts, clinopyroxenes, plagioclases, titanomagnetites, and olivines. SD is the standard deviation.

\begin{tabular}{|c|c|c|c|c|c|c|c|c|c|c|c|c|c|c|c|c|}
\hline$\#$ & HE-2 & SD(4) & HE-3 & $\mathrm{SD}(4)$ & ME-1 & SD(4) & ME-2 & $\mathrm{SD}(4)$ & ME-4 & $\mathrm{SD}(4)$ & ME-5 & SD(4) & ME-6 & SD(4) & ME-7 & SD(4) \\
\hline \multicolumn{17}{|c|}{ Experimental melt compositions } \\
\hline $\mathrm{SiO}_{2}$ & 50.96 & 0.40 & 51.71 & 0.38 & 49.88 & 0.45 & 50.86 & 0.43 & 50.69 & 0.45 & 53.51 & 0.42 & 53.21 & 0.45 & 53.49 & 0.41 \\
\hline $\mathrm{TiO}_{2}$ & 2.00 & 0.02 & 1.49 & 0.02 & 1.75 & 0.02 & 2.00 & 0.03 & 1.92 & 0.03 & 1.89 & 0.02 & 1.86 & 0.03 & 2.05 & 0.02 \\
\hline $\mathrm{FeO}$ & 8.35 & 0.10 & 6.08 & 0.06 & 9.59 & 0.14 & 9.50 & 0.09 & 9.57 & 0.10 & 7.40 & 0.07 & 7.08 & 0.07 & 8.35 & 0.12 \\
\hline $\mathrm{MnO}$ & 0.16 & 0.02 & 0.20 & 0.03 & 0.14 & 0.00 & 0.20 & 0.02 & 0.22 & 0.01 & 0.21 & 0.03 & 0.24 & 0.01 & 0.20 & 0.01 \\
\hline $\mathrm{MgO}$ & 3.29 & 0.06 & 4.23 & 0.07 & 4.64 & 0.09 & 3.79 & 0.04 & 3.91 & 0.05 & 2.45 & 0.05 & 2.80 & 0.03 & 4.21 & 0.08 \\
\hline $\mathrm{CaO}$ & 7.03 & 0.06 & 9.65 & 0.11 & 9.39 & 0.07 & 7.41 & 0.07 & 7.05 & 0.07 & 5.76 & 0.04 & 5.60 & 0.05 & 7.36 & 0.07 \\
\hline $\mathrm{K}_{2} \mathrm{O}$ & 3.31 & 0.07 & 2.23 & 0.03 & 2.22 & 0.03 & 3.12 & 0.05 & 3.20 & 0.08 & 4.32 & 0.06 & 4.16 & 0.06 & 3.02 & 0.07 \\
\hline $\mathrm{P}_{2} \mathrm{O}_{5}$ & 0.98 & 0.02 & 0.33 & 0.02 & 0.49 & 0.01 & 0.67 & 0.03 & 0.70 & 0.03 & 0.86 & 0.04 & 0.89 & 0.02 & 0.72 & 0.03 \\
\hline Total & 97.91 & & 91.82 & & 96.82 & & 97.68 & & 97.60 & & 95.90 & & 96.19 & & 95.02 & \\
\hline$\#$ & HE-2 & SD(3) & HE-3 & $\mathrm{SD}(3)$ & ME-1 & SD(3) & ME-2 & $\mathrm{SD}(3)$ & ME-4 & $\mathrm{SD}(3)$ & ME-5 & SD(3) & ME-6 & SD(3) & ME-7 & $\mathrm{SD}(3)$ \\
\hline \multicolumn{17}{|c|}{ Experimental clinopyroxene compositions } \\
\hline $\mathrm{SiO}_{2}$ & 47.86 & 0.39 & 48.95 & 0.40 & 48.95 & 0.40 & 48.56 & 0.39 & 49.56 & 0.40 & 49.35 & 0.40 & 49.29 & 0.40 & 48.73 & 0.39 \\
\hline $\mathrm{TiO}_{2}$ & 1.85 & 0.02 & 0.88 & 0.01 & 1.51 & 0.02 & 1.54 & 0.02 & 1.36 & 0.02 & 1.55 & 0.02 & 1.26 & 0.02 & 1.52 & 0.02 \\
\hline $\mathrm{Al}_{2} \mathrm{O}_{3}$ & 6.22 & 0.12 & 5.34 & 0.10 & 4.98 & 0.09 & 5.34 & 0.10 & 4.56 & 0.09 & 4.52 & 0.09 & 4.63 & 0.09 & 4.99 & 0.09 \\
\hline $\mathrm{MgO}$ & 12.25 & 0.15 & 14.86 & 0.18 & 12.79 & 0.15 & 12.57 & 0.15 & 13.15 & 0.16 & 12.64 & 0.15 & 13.49 & 0.16 & 12.74 & 0.15 \\
\hline $\mathrm{CaO}$ & 22.40 & 0.27 & 22.46 & 0.27 & 22.77 & 0.27 & 22.54 & 0.27 & 21.79 & 0.26 & 22.13 & 0.27 & 22.89 & 0.27 & 22.68 & 0.27 \\
\hline $\mathrm{Na}_{2} \mathrm{O}$ & 0.42 & 0.03 & 0.60 & 0.04 & 0.47 & 0.03 & 0.48 & 0.03 & 0.53 & 0.03 & 0.58 & 0.03 & 0.73 & 0.04 & 0.44 & 0.03 \\
\hline Total & 99.77 & & 99.93 & & 99.99 & & 99.74 & & 99.39 & & 99.81 & & 100.17 & & 99.76 & \\
\hline \multicolumn{17}{|c|}{ Cations on the basis of 6 oxygens } \\
\hline $\mathrm{Si}$ & 1.789 & & 1.796 & & 1.822 & & 1.813 & & 1.853 & & 1.843 & & 1.631 & & 1.819 & \\
\hline $\mathrm{Ti}$ & 0.211 & & 0.204 & & 0.178 & & 0.187 & & 0.147 & & 0.157 & & 0.169 & & 0.181 & \\
\hline $\mathrm{Al}^{\mathrm{IV}}$ & 0.063 & & 0.027 & & 0.040 & & 0.048 & & 0.053 & & 0.042 & & 0.032 & & 0.038 & \\
\hline $\mathrm{Al}^{\mathrm{VI}}$ & 0.052 & & 0.024 & & 0.042 & & 0.043 & & 0.038 & & 0.043 & & 0.035 & & 0.043 & \\
\hline $\mathrm{Fe}^{3+}$ & 0.076 & & 0.172 & & 0.089 & & 0.089 & & 0.056 & & 0.072 & & 0.121 & & 0.092 & \\
\hline $\mathrm{Fe}^{2+}$ & 0.192 & & 0.033 & & 0.170 & & 0.178 & & 0.201 & & 0.199 & & 0.115 & & 0.173 & \\
\hline
\end{tabular}


Table 3. Cont

\begin{tabular}{|c|c|c|c|c|c|c|c|c|c|c|c|c|c|c|c|}
\hline \multicolumn{16}{|c|}{ Cations on the basis of 6 oxygens } \\
\hline $\mathrm{Mn}$ & 0.682 & & 0.813 & & 0.710 & & 0.699 & & 0.733 & & 0.703 & & 0.738 & & 0.709 \\
\hline $\mathrm{Mg}$ & 0.006 & & 0.005 & & 0.006 & & 0.005 & & 0.007 & & 0.012 & & 0.006 & & 0.006 \\
\hline $\mathrm{Ca}$ & 0.897 & & 0.883 & & 0.908 & & 0.902 & & 0.873 & & 0.886 & & 0.900 & & 0.907 \\
\hline $\mathrm{Na}$ & 0.030 & & 0.042 & & 0.034 & & 0.035 & & 0.038 & & 0.042 & & 0.052 & & 0.032 \\
\hline Di & 0.58 & & 0.67 & & 0.62 & & 0.60 & & 0.60 & & 0.60 & & 0.65 & & 0.62 \\
\hline $\mathrm{Hd}$ & 0.16 & & 0.03 & & 0.15 & & 0.15 & & 0.16 & & 0.17 & & 0.10 & & 0.15 \\
\hline En & 0.05 & & 0.07 & & 0.04 & & 0.05 & & 0.07 & & 0.05 & & 0.04 & & 0.05 \\
\hline Fs & 0.02 & & 0.00 & & 0.01 & & 0.01 & & 0.02 & & 0.01 & & 0.01 & & 0.01 \\
\hline Jd & 0.03 & & 0.03 & & 0.04 & & 0.04 & & 0.04 & & 0.04 & & 0.03 & & 0.03 \\
\hline CaTs & 0.07 & & 0.08 & & 0.05 & & 0.06 & & 0.04 & & 0.04 & & 0.05 & & 0.05 \\
\hline CaFeTs & 0.04 & & 0.09 & & 0.04 & & 0.04 & & 0.03 & & 0.04 & & 0.06 & & 0.05 \\
\hline$\#$ & HE-2 & $\mathrm{SD}(3)$ & ME-1 & $\mathrm{SD}(3)$ & ME-2 & $\mathrm{SD}(3)$ & ME-4 & $\mathrm{SD}(3)$ & ME-5 & $\mathrm{SD}(3)$ & ME-6 & $\mathrm{SD}(3)$ & ME-7 & $\mathrm{SD}(3)$ & \\
\hline \multicolumn{16}{|c|}{ Experimental plagioclase compositions } \\
\hline $\mathrm{SiO}_{2}$ & 46.72 & 0.38 & 48.91 & 0.40 & 52.40 & 0.42 & 52.10 & 0.42 & 52.30 & 0.42 & 50.21 & 0.41 & 51.27 & 0.42 & \\
\hline $\mathrm{TiO}_{2}$ & 0.12 & 0.01 & 0.05 & 0.00 & 0.09 & 0.01 & 0.08 & 0.01 & 0.10 & 0.01 & 0.07 & 0.01 & 0.11 & 0.01 & \\
\hline $\mathrm{Al}_{2} \mathrm{O}_{3}$ & 32.31 & 0.36 & 31.35 & 0.34 & 28.99 & 0.32 & 29.92 & 0.33 & 28.75 & 0.32 & 30.42 & 0.33 & 29.99 & 0.33 & \\
\hline $\mathrm{FeO}$ & 0.96 & 0.04 & 0.80 & 0.03 & 0.81 & 0.03 & 0.85 & 0.04 & 1.10 & 0.05 & 0.98 & 0.04 & 0.94 & 0.04 & \\
\hline $\mathrm{MgO}$ & 0.10 & 0.01 & 0.09 & 0.01 & 0.09 & 0.01 & 0.09 & 0.01 & 0.16 & 0.01 & 0.09 & 0.01 & 0.10 & 0.01 & \\
\hline $\mathrm{CaO}$ & 16.61 & 0.20 & 15.46 & 0.19 & 13.01 & 0.16 & 13.62 & 0.16 & 13.07 & 0.16 & 14.08 & 0.17 & 13.74 & 0.16 & \\
\hline $\mathrm{Na}_{2} \mathrm{O}$ & 2.98 & 0.13 & 2.67 & 0.11 & 3.99 & 0.17 & 3.51 & 0.15 & 3.81 & 0.16 & 3.81 & 0.16 & 3.43 & 0.14 & \\
\hline $\mathrm{K}_{2} \mathrm{O}$ & 0.16 & 0.01 & 0.21 & 0.01 & 0.44 & 0.03 & 0.34 & 0.02 & 0.45 & 0.03 & 0.31 & 0.02 & 0.38 & 0.02 & \\
\hline Total & 99.96 & & 99.53 & & 99.82 & & 100.51 & & 99.74 & & 99.96 & & 99.97 & & \\
\hline \multicolumn{16}{|c|}{ Cations on the basis of 8 oxygens } \\
\hline $\mathrm{Si}$ & 2.164 & & 2.253 & & 2.391 & & 2.361 & & 2.390 & & 2.301 & & 2.341 & & \\
\hline $\mathrm{Al}$ & 1.764 & & 1.702 & & 1.560 & & 1.598 & & 1.549 & & 1.644 & & 1.614 & & \\
\hline $\mathrm{Fe}$ & 0.037 & & 0.031 & & 0.031 & & 0.032 & & 0.042 & & 0.037 & & 0.036 & & \\
\hline $\mathrm{Mg}$ & 0.001 & & 0.001 & & 0.001 & & 0.001 & & 0.001 & & 0.001 & & 0.001 & & \\
\hline $\mathrm{Ca}$ & 0.824 & & 0.763 & & 0.636 & & 0.661 & & 0.640 & & 0.692 & & 0.672 & & \\
\hline $\mathrm{Na}$ & 0.268 & & 0.238 & & 0.353 & & 0.308 & & 0.338 & & 0.339 & & 0.304 & & \\
\hline K & 0.010 & & 0.012 & & 0.025 & & 0.019 & & 0.026 & & 0.018 & & 0.022 & & \\
\hline An & 75 & & 75 & & 63 & & 67 & & 64 & & 66 & & 67 & & \\
\hline $\mathrm{Ab}$ & 24 & & 24 & & 35 & & 31 & & 34 & & 32 & & 30 & & \\
\hline Or & 1 & & 1 & & 2 & & 2 & & 3 & & 2 & & 2 & & \\
\hline
\end{tabular}


Table 3. Cont.

\begin{tabular}{|c|c|c|c|c|c|c|c|c|c|c|c|c|}
\hline$\#$ & HE-2 & SD(3) & HE-3 & $\mathrm{SD}(3)$ & ME-5 & $\mathrm{SD}(3)$ & & & & & & \\
\hline \multicolumn{13}{|c|}{ Experimental titanomagnetite compositions } \\
\hline $\mathrm{TiO}_{2}$ & 10.15 & 0.11 & 10.14 & 0.12 & 10.03 & 0.12 & & & & & & \\
\hline $\mathrm{Al}_{2} \mathrm{O}_{3}$ & 6.32 & 0.32 & 5.28 & 0.26 & 5.43 & 0.27 & & & & & & \\
\hline $\mathrm{FeO}$ & 73.01 & 0.66 & 71.45 & 0.79 & 74.61 & 0.60 & & & & & & \\
\hline $\mathrm{MnO}$ & 0.38 & 0.05 & 0.62 & 0.07 & 0.42 & 0.05 & & & & & & \\
\hline $\mathrm{MgO}$ & 4.19 & 0.25 & 1.53 & 0.09 & 1.89 & 0.11 & & & & & & \\
\hline Total & 94.05 & & 89.01 & & 92.38 & & & & & & & \\
\hline \multicolumn{13}{|c|}{ Cations on the basis of 3 oxygens } \\
\hline $\mathrm{Ti}$ & 0.275 & & 0.297 & & 0.283 & & & & & & & \\
\hline $\mathrm{Al}$ & 0.269 & & 0.243 & & 0.240 & & & & & & & \\
\hline $\mathrm{Fe} 3+$ & 0.000 & & 0.000 & & 0.000 & & & & & & & \\
\hline $\mathrm{Fe} 2+$ & 2.203 & & 2.330 & & 2.340 & & & & & & & \\
\hline $\mathrm{Mn}$ & 0.012 & & 0.020 & & 0.013 & & & & & & & \\
\hline $\mathrm{Mg}$ & 0.225 & & 0.089 & & 0.106 & & & & & & & \\
\hline Usp & 32 & & 37 & & 34 & & & & & & & \\
\hline$\#$ & HE-2 & $\mathrm{SD}(3)$ & ME-2 & $\mathrm{SD}(3)$ & ME-4 & $\mathrm{SD}(3)$ & ME-5 & $\mathrm{SD}(3)$ & ME-6 & $\mathrm{SD}(3)$ & ME-7 & $\mathrm{SD}(3)$ \\
\hline \multicolumn{13}{|c|}{ Experimental olivine compositions } \\
\hline $\mathrm{SiO}_{2}$ & 37.28 & 0.30 & 38.34 & 0.31 & 38.57 & 0.31 & 38.07 & 0.31 & 37.28 & 0.30 & 38.07 & 0.31 \\
\hline $\mathrm{FeO}$ & 30.13 & 0.36 & 22.81 & 0.27 & 24.79 & 0.30 & 23.33 & 0.28 & 30.13 & 0.36 & 23.33 & 0.28 \\
\hline $\mathrm{MnO}$ & 0.74 & 0.04 & 0.66 & 0.03 & 0.64 & 0.03 & 0.59 & 0.03 & 0.74 & 0.04 & 0.59 & 0.03 \\
\hline $\mathrm{MgO}$ & 31.08 & 0.34 & 36.57 & 0.40 & 35.28 & 0.39 & 36.47 & 0.40 & 31.08 & 0.34 & 36.47 & 0.40 \\
\hline $\mathrm{CaO}$ & 0.43 & 0.03 & 0.44 & 0.04 & 0.44 & 0.02 & 0.39 & 0.03 & 0.43 & 0.02 & 0.39 & 0.03 \\
\hline Tot & 99.66 & & 98.82 & & 99.72 & & 98.85 & & 99.66 & & 98.85 & \\
\hline \multicolumn{13}{|c|}{ Cations on the basis of 4 oxygens } \\
\hline $\mathrm{Si}$ & 1.013 & & 1.014 & & 1.018 & & 1.009 & & 1.013 & & 1.009 & \\
\hline $\mathrm{Fe}$ & 0.685 & & 0.504 & & 0.547 & & 0.517 & & 0.685 & & 0.517 & \\
\hline Mn & 0.017 & & 0.015 & & 0.014 & & 0.013 & & 0.017 & & 0.013 & \\
\hline $\mathrm{Mg}$ & 1.259 & & 1.441 & & 1.389 & & 1.441 & & 1.259 & & 1.441 & \\
\hline $\mathrm{Ca}$ & 0.013 & & 0.012 & & 0.012 & & 0.011 & & 0.013 & & 0.011 & \\
\hline Fo & 65 & & 74 & & 72 & & 74 & & 65 & & 74 & \\
\hline
\end{tabular}




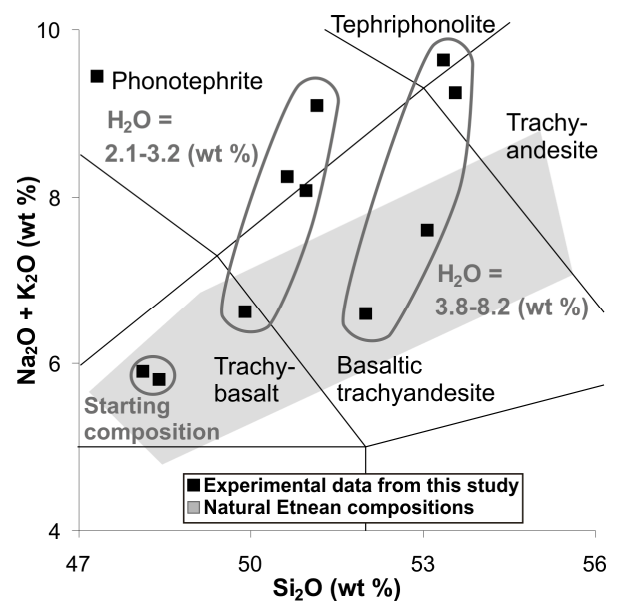

Figure 2. Total alkali vs. silica diagram showing the composition of residual melts from our experiments. Two distinct trends are depicted as a function of the $\mathrm{H}_{2} \mathrm{O}$ content. For $\mathrm{H}_{2} \mathrm{O}=2.1-3.2 \mathrm{wt} \%$, the original trachybasaltic liquid evolves towards basaltic trachyandesitic and phonotephritic compositions. For $\mathrm{H}_{2} \mathrm{O}=3.8-8.2 \mathrm{wt} \%$, the starting melt differentiates to basaltic trachyandesitic to trachyandesitic to tephriphonolitic compositions.

The amount of diopside (Di) and hedenbergite $(\mathrm{Hd})$ in clinopyroxene generally decreases with increasing temperature and $\mathrm{H}_{2} \mathrm{O}$ (Table 3). At $\mathrm{H}_{2} \mathrm{O}=2.1-3.2$ wt \%, the ferri-calcium Tschermak molecule (CaFeTs) slightly decreases with decreasing temperature (Figure $3 a)$. Conversely, at $\mathrm{H}_{2} \mathrm{O}=3.8-8.2 \mathrm{wt} \%$, both $\mathrm{Al}^{\mathrm{iv}}$ and $\mathrm{Fe}^{3+}$ are preferentially incorporated into clinopyroxene crystal lattice, leading to higher CaFeTs contents [33].
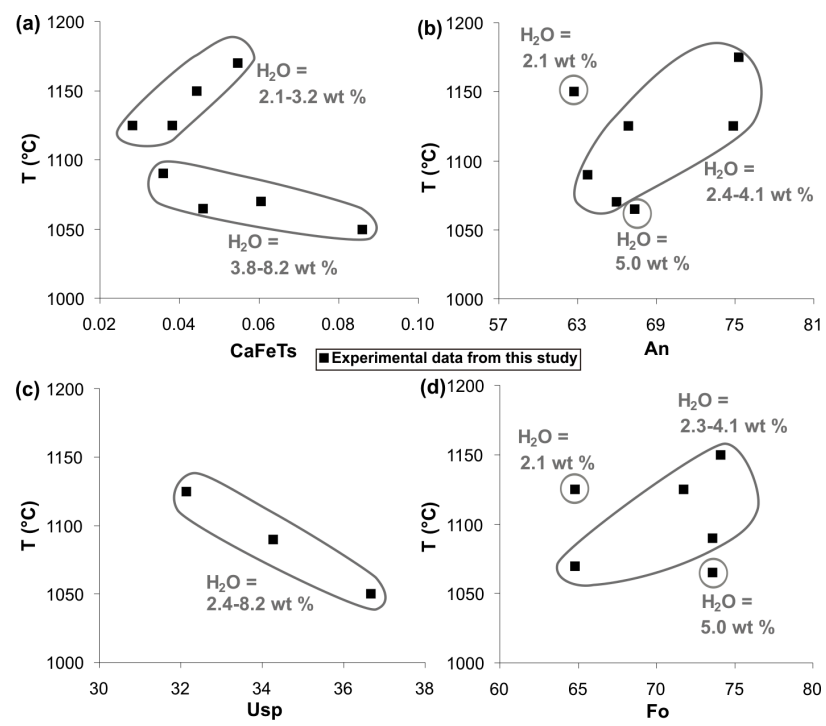

Figure 3. Mineral compositional variations as a function of temperature and melt $-\mathrm{H}_{2} \mathrm{O}$ content. At $\mathrm{H}_{2} \mathrm{O}=2.1-3.2 \mathrm{wt} \%$, the ferri-calcium Tschermak molecule (CaFeTs) slightly decreases with decreasing temperature, whereas at $\mathrm{H}_{2} \mathrm{O}=3.8-8.2 \mathrm{wt} \%$, both $\mathrm{Al}^{\mathrm{iv}}$ and $\mathrm{Fe}^{3+}$ are preferentially incorporated into clinopyroxene crystal lattice, leading to higher CaFeTs contents (a). The anorthite (An) molecule in plagioclase generally decreases with decreasing temperature with the exception of compositions derived upon the effect of $\mathrm{H}_{2} \mathrm{O}=2.1$ and $5 \mathrm{wt} \%(\mathbf{b})$. The ulvospinel (Usp) content in titanomagnetite progressively increases along an almost linear trend resulting from the combined effect of both temperature and $\mathrm{H}_{2} \mathrm{O}(\mathrm{c})$. At $\mathrm{H}_{2} \mathrm{O}=2.3-3.8 \mathrm{wt} \%$, the amount of forsterite ( $\mathrm{Fo}$ ) in olivine decreases with decreasing temperature, whereas scattered Fo values are observed at $\mathrm{H}_{2} \mathrm{O}=2.1$ and 5 wt $\%(d)$. 
Overall, the anorthite (An) molecule in plagioclase shows a rough decrease (from $\mathrm{An}_{75}$ to $\mathrm{An}_{63}$ ) with decreasing temperature (Figure $3 b$ ). However, An in plagioclase is also influenced by the initial $\mathrm{H}_{2} \mathrm{O}$ content, according to the dependence of $\mathrm{CaO}-\mathrm{NaO}$ exchange on hydroxyl groups dissolved in the melt [34].

The ulvospinel (Usp) content in titanomagnetite progressively increases along an almost linear trend resulting from the combined effect of both temperature and $\mathrm{H}_{2} \mathrm{O}$ (Figure 3c). This compositional change is also associated with lower $\mathrm{Al}$ and $\mathrm{Mg}$ concentrations into the titanomagnetite crystal lattice, due to their preferential incorporation in clinopyroxene and plagioclase (Table 3).

At $\mathrm{H}_{2} \mathrm{O}=2.3-3.8 \mathrm{wt} \%$, the amount of forsterite ( $\mathrm{Fo}$ ) in olivine decreases from 74 to 65 with decreasing temperature, whereas scattered Fo values are observed at the $\mathrm{H}_{2} \mathrm{O}=2.1$ and 5 (Figure 3d). As documented for plagioclase, hydroxyl groups dissolved in the melt preferentially complex with $\mathrm{Mg}^{2+}$ rather than $\mathrm{Fe}^{2+}$, thus reducing the activity of $\mathrm{MgO}$ relative to $\mathrm{FeO}$ in olivine, and viceversa [34].

\subsection{Achievement of Equilibrium}

In order to test the achievement of equilibrium crystallization in the experimental charges, different textural and compositional features have been considered: (1) the euhedral shape of crystals, (2) the homogeneous distribution of mineral phases in the glass, (3) the lack of quench crystals, (4) the smooth variation of phase compositions with experimental conditions, (5) the small sum of residuals (generally $\leq 0.5$; Table 2) from mass-balance calculations, and (6) crystal-melt exchange coefficients (Kd) for clinopyroxene and plagioclase comparable to those from previous equilibrium studies. Concerning the clinopyroxene phase, we have used the temperature-sensitive ${ }^{\text {cpx-melt }} \mathrm{Kd} \mathrm{Fe}_{\mathrm{Fe}} \mathrm{Mg}$ model derived by Putirka [35] and based on deviations in observed and calculated Fe-Mg cation partitioning between crystals and coexisting melts. ${ }^{\text {cpx-melt }} \mathrm{Kd} \mathrm{de}_{\mathrm{Fe}} \mathrm{Mg}$ values of clinopyroxene-melt pairs from this study, calculated with the total $\mathrm{Fe}$ as $\mathrm{Fe}^{2+}$ according to Putirka et al. [36], vary between 0.26 and 0.27 (Table 2), in agreement with the equilibrium range of $0.27 \pm 0.03$ reported in literature (e.g., [36]). As a further test for clinopyroxene, we have also adopted the model of Mollo et al. [37], calibrated through the difference between diopside + hedenbergite components $(\Delta \mathrm{DiHd})$ predicted for clinopyroxene via regression analysis of clinopyroxene-melt pairs in equilibrium conditions, and those measured in the analyzed crystals (Table 2). $\triangle \mathrm{DiHd}$ values derived for our experimental compositions are remarkably low (0.03-0.08) and close to zero, as expected for thermodynamically equilibrated phases (e.g., [38]).

The equilibrium crystallization of plagioclase has been tested through the Ab-An (albite-anorthite) exchange reaction proposed by Putirka [35]. According to this model, the equilibrium constant is constrained within two temperature-dependent intervals of ${ }^{\text {plg-melt }} \mathrm{Kd}_{\mathrm{Ab}-\mathrm{An}}=0.10 \pm 0.05$ at $T<1050{ }^{\circ} \mathrm{C}$ and ${ }^{\text {plg-melt }} \mathrm{Kd} \mathrm{Ab}_{\mathrm{An}}=0.25 \pm 0.11$ at $T>1050{ }^{\circ} \mathrm{C}$. Our estimates show that ${ }^{\text {plg-melt }} \mathrm{Kd}$ Ab-An yields values between 0.15 and 0.21 , suggesting equilibrium crystallization for experimental plagioclase crystals formed at $T>1050^{\circ} \mathrm{C}$.

\section{Discussion}

\section{1. $\mathrm{H}_{2} \mathrm{O}$-Undersaturated Versus $\mathrm{H}_{2} \mathrm{O}$-Saturated Crystallization Regimes}

Previous experiments conducted at 200-400 MPa on Etnean magmas have demonstrated that olivine does not crystallize under $\mathrm{H}_{2} \mathrm{O}$-undersaturated conditions $[12,17,39]$, whereas at $\mathrm{P}_{\mathrm{H} 2 \mathrm{O}}=\mathrm{P}_{\text {total }}$ its stability field expands at the expense of other minerals, and olivine appears as liquidus phase [16]. A similar result has been also documented by the experimental study of Di Carlo et al. [40] for a K-basalt from Stromboli, where clinopyroxene dominates the phase assemblage at 400 and $300 \mathrm{MPa}$. Clinopyroxene and olivine co-saturate the melt at $200 \mathrm{MPa}$ and olivine becomes the liquidus phase at $100 \mathrm{MPa}$ and $\mathrm{H}_{2} \mathrm{O}>3.5 \mathrm{wt} \%$ [40]. Our experiments confirm that olivine is a late crystallizing phase from $\mathrm{H}_{2} \mathrm{O}$-undersaturated magmas equilibrated at high pressure. This agrees with the petrological observation of Tanguy et al. [41] that clinopyroxene oversteps olivine crystallization at the Moho depth (28 km, $\sim 800 \mathrm{MPa}$; [18]), for most of the trachybasaltic lava flows erupted at Mt. Etna. Moreover, 
thermobarometric estimates demonstrate that the initial stages of crystallization of Etnean trachybasalts take place near the Moho boundary [21], pointing to a deep feeder level of the plumbing system. We are aware of the critical role of $\mathrm{CO}_{2}$ on the activity of $\mathrm{H}_{2} \mathrm{O}$ in the melt and degassing/crystallization processes at Mt. Etna volcano, especially at high pressure, where the solubility of $\mathrm{CO}_{2}$ may be significant (e.g., up to $\sim 0.7$ wt \% at $800 \mathrm{MPa}$; [19]). However, previous experiments on Etnean trachybasalts show that phase relations and compositions are weakly affected by $\mathrm{CO}_{2}$ concentration in the melt, successfully reproducing the textures and compositions of natural products under $\mathrm{CO}_{2}$-absent experimental conditions. For example, Vetere et al. [17] have performed experiments on Etnean trachybasalts equilibrated at $400 \mathrm{MPa}, 1100-1150{ }^{\circ} \mathrm{C}$ and $\mathrm{NNO}+3.7$ buffering conditions, as well as in presence of volatile components of $1-3$ wt $\% \mathrm{H}_{2} \mathrm{O}$ and $0-0.3 \mathrm{wt} \% \mathrm{CO}_{2}$. Results from these experiments indicate that the role of $\mathrm{CO}_{2}$ in controlling the final composition of magmas is negligible with respect to that played by $\mathrm{T}$ and $\mathrm{H}_{2} \mathrm{O}$ at degrees of crystal fractionation in the range of $6-40 \mathrm{wt} \%$. More specifically, in terms of major and rare earth elements, the Etnean compositions are well reproduced in laboratory irrespective of the $\mathrm{C}-\mathrm{O}-\mathrm{H}$ species in the melt phase. Logically, an increasing concentration of $\mathrm{CO}_{2}$ in the melt reduces the solubility of $\mathrm{H}_{2} \mathrm{O}$, thus modulating the degree of crystal fractionation, as it is obtained by lowering the amount of $\mathrm{H}_{2} \mathrm{O}$ added in the experimental charge.

In Figure 4, the compositions of pre-historic, 1963-1995, and 2001-2006 lava flows at Mt. Etna are compared with those experimentally derived at high $(\mathrm{P}=800 \mathrm{MPa})$, moderate $(\mathrm{P}=200-400 \mathrm{MPa})$ and low ( $\mathrm{P}=27-120 \mathrm{MPa})$ pressures (Table S1, Supplementary Materials). In $\mathrm{H}_{2} \mathrm{O}$-undersaturated experiments conducted at both high and moderate pressures, plagioclase crystallization is favored at low $\mathrm{H}_{2} \mathrm{O}$ content, leading to a relatively high plagioclase/clinopyroxene ratio (Plg/Cpx $\left.=0.7-2.2\right)$. As a consequence, the $\mathrm{CaO} / \mathrm{K}_{2} \mathrm{O}$ ratio in the melt decreases significantly at the early stage of crystallization, reproducing the bulk rock compositions of 2001-2006 eruptions, as well as part of the evolutionary trend of the less differentiated historic eruptions. In contrast, the high $\mathrm{H}_{2} \mathrm{O}$ content in the low pressure experiments suppresses the crystallization of plagioclase along most of the magma differentiation path. Plagioclase starts to crystallize at low temperature $\left(1075^{\circ} \mathrm{C}\right)$ and the plagioclase/clinopyroxene ratio remains relatively low $(\mathrm{Plg} / \mathrm{Cpx}=0.3-0.9)$. Thus, the experimental melts exhibit high $\mathrm{CaO} / \mathrm{K}_{2} \mathrm{O}$ ratios that capture the bulk rock compositions of 1763-1995 eruptions.

According to Figure 4, it is apparent that the differentiation of Etnean magmas is controlled by the stability of plagioclase that, in turn, depends on the amount of $\mathrm{H}_{2} \mathrm{O}$ dissolved in the melt. At very shallow crustal levels, the core-to-rim compositional variation of plagioclase phenocrysts is driven by the exsolution of $\sim 3 \mathrm{wt} \% \mathrm{H}_{2} \mathrm{O}$ during magma decompression from 85 to $5 \mathrm{MPa}$ [12]. Conversely, at $\mathrm{P}>100 \mathrm{MPa}$, disequilibrium textures of plagioclase testify to mixing induced by recharge of volatile-rich magmas or injection by volatile flushing into the system $[9,24]$. This applies especially to the onset of lava fountain eruptions that are triggered by the irregular arrival of primitive, volatile-rich magma batches that mixed with more evolved, $\mathrm{H}_{2} \mathrm{O}$-undersaturated trachybasalts residing in the upper conduit region of the volcano [1,23].

In order to explain the most differentiated trachyandesitic lavas erupted during the pre-historic activity of Mt. Etna, we have modelled the evolution of the HE trachybasalt using the MELTS algorithm of Ghiorso and Sack [42] assuming a fractional crystallization process. The best fitting differentiation path is obtained at $1040-1160{ }^{\circ} \mathrm{C}, 150 \mathrm{MPa}, 1.5 \mathrm{wt} \% \mathrm{H}_{2} \mathrm{O}$ and NNO buffer, when the system is $\mathrm{H}_{2} \mathrm{O}$-undersaturated, but the $\mathrm{H}_{2} \mathrm{O}$ concentration increases from 1.5 to $3.2 \mathrm{wt} \%$ during crystallization (Table S2, Supplementary Materials). Under such circumstances, the plagioclase/clinopyroxene ratio is intermediate $(\mathrm{Plg} / \mathrm{Cpx}=0.3-1.8)$ to that experimentally derived at low and high pressure conditions (Figure 4), thus reproducing the bulk rock trachyandesitic compositions of natural products. This finding confirms the differentiation model proposed by [41], where pre-historic trachybasaltic magmas underwent occasional pulses of low-pressure plagioclase fractionation causing the eruption of more evolved trachyandesitic lava flows. Importantly, high-pressure experiments from this study point out that, at $\mathrm{H}_{2} \mathrm{O}=2.1-3.2 \mathrm{wt} \%$, the degree of crystallization is generally very high $(\sim 40-50 \mathrm{vol} \%)$, 
so that deep-seated trachybasaltic magmas shift towards phonotephritic compositions never erupted during the entire volcanic activity of Mt. Etna.

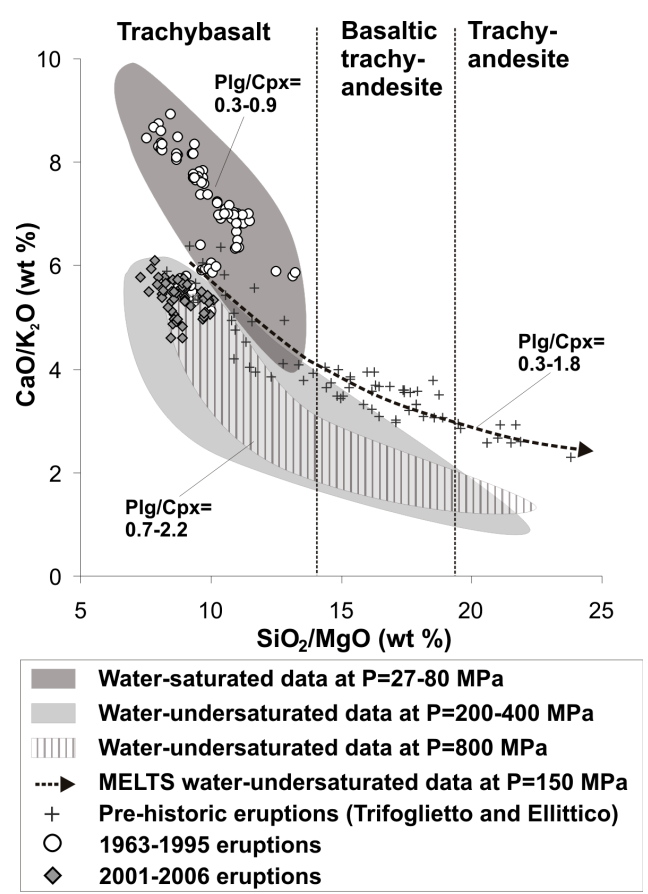

Figure 4. The compositions of pre-historic, 1963-1995, and 2001-2006 lava flows at Mt. Etna (data are from the GEOROC database-http:/ /georoc.mpch-mainz.gwdg.de/georoc/Start.asp) are compared with those experimentally derived at high $(\mathrm{P}=800 \mathrm{MPa})$, moderate $(\mathrm{P}=200-400 \mathrm{MPa})$ and low $(\mathrm{P}=27-120 \mathrm{MPa})$ pressures, as well as MELTS [42] simulations on $\mathrm{HE}$ trachybasalt equilibrated at $1000-1160{ }^{\circ} \mathrm{C}, 150 \mathrm{MPa}, 1.5 \mathrm{wt} \% \mathrm{H}_{2} \mathrm{O}$ and $\mathrm{NNO}$ buffer (see dashed line). The $\mathrm{Plg} / \mathrm{Cpx}$ ratio changes upon the effect of $\mathrm{H}_{2} \mathrm{O}$-saturated and $\mathrm{H}_{2} \mathrm{O}$-undersaturated conditions, controlling the $\mathrm{CaO} / \mathrm{K}_{2} \mathrm{O}$ ratio of the melt. Plg, plagioclase. Cpx, clinopyroxene.

\section{2. $\mathrm{H}_{2} \mathrm{O}$ Release upon Magma Ascent during 2001 and 2006 Eruptions}

Through the thermodynamically based equation of state proposed by Duan [19], we have estimated the solubility of $\mathrm{H}_{2} \mathrm{O}$ and $\mathrm{CO}_{2}$ in Etnean magmas. One of the advantages of this model consists of its applicability to high pressure ( $>500 \mathrm{MPa}$ ) and high temperature conditions that are not adequately reproduced by previous equations (see [20] for a review). Our calculations referred to 100-800 MPa and $1200^{\circ} \mathrm{C}$ using the HE trachybasalt as input composition (Table 1); notably, replicated calculations at $1100-1150{ }^{\circ} \mathrm{C}$ with more or less differentiated trachybasalts $(\mathrm{MgO}=4-6 \mathrm{wt} \%$ as for 2001-2012 Etnean lavas; [12]) provided changes in estimate (6.5\%) within the accuracy of the model for the prediction of $\mathrm{H}_{2} \mathrm{O}(7.2 \%)$ and $\mathrm{CO}_{2}(9.7 \%)$. Results are plotted in Figure 5a together with the volatile contents derived by melt inclusion data from 2001 and 2006 lava flows $[3,14,43]$. Generally, the molar fraction of $\mathrm{H}_{2} \mathrm{O}$ in the gas phase ranges from 20 to $40 \mathrm{~mol} \%$ as documented by Collins et al. [3] and, at $400 \mathrm{MPa}$, the maximum concentrations of $\mathrm{H}_{2} \mathrm{O}$ and $\mathrm{CO}_{2}$ are $3.5 \mathrm{wt} \%$ and $0.3 \mathrm{wt} \%$, respectively (Figure 5a). The amount of volatiles dissolved in the 2001 magma is also higher than that measured for the 2006 eruption. Indeed, the 2001 lava flow was fed by a volatile-rich primitive basalt rising along a closed-system degassing path [14,43], whereas the 2006 eruption involved the slow effusion of a gas-poor magma ponding within the volcanic edifice [3,44]. An important outcome from our calculations is that, at $800 \mathrm{MPa}$, the solubility of $\mathrm{H}_{2} \mathrm{O}$ can be very high, ranging from 6 to $8.5 \mathrm{wt} \%$ (Figure 5a). Therefore, trachybasaltic magmas stored at the Moho depth may be source of sustained $\mathrm{H}_{2} \mathrm{O}$ supply during upward migration throughout the plumbing system of the volcano. 


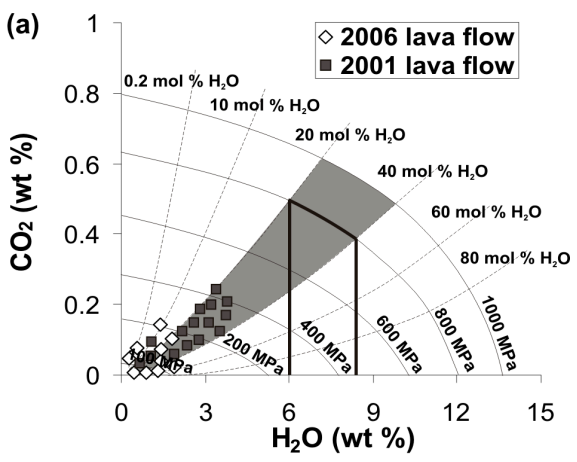

(b)

$\mathrm{T}\left({ }^{\circ} \mathrm{C}\right)$

1040107011001130116011901220

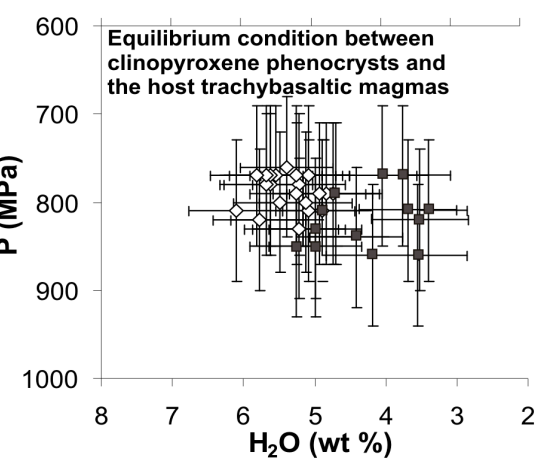

Figure 5. $\mathrm{H}_{2} \mathrm{O}$ vs. $\mathrm{CO}_{2}$ solubility diagram derived through the model of Duan [19] (a). Calculations were referred to $100-800 \mathrm{MPa}$ and $1200{ }^{\circ} \mathrm{C}$ using the $\mathrm{HE}$ trachybasalt as input composition. The volatile contents derived by melt inclusion data from 2001 and 2006 lava flows $[3,14,43]$ are also plotted in figure. P-T- $\mathrm{H}_{2} \mathrm{O}$ diagram derived for the stability of clinopyroxene phenocrysts from 2001 and 2006 lava flows (b). The saturation pressure $(\sim 800 \mathrm{MPa})$ and temperature $\left(1120-1200{ }^{\circ} \mathrm{C}\right.$ and $1080-1150{ }^{\circ} \mathrm{C}$ for the 2001 and 2006 clinopyroxenes, respectively) were estimated by Armienti et al. [21]. Our experimental data, indicate that the original amounts of $\mathrm{H}_{2} \mathrm{O}$ in equilibrium with 2001 and 2006 magmas were 3-6 and 5.5-7 wt \%, respectively. Error bars come from thermometric and hygrometric estimates of Armienti et al. [21].

Using a specific algorithm based on the equilibrium partitioning between mineral and melt, Armienti et al. [21] estimated the near-liquidus temperature of Etnean trachybasaltic magmas at the early stage of clinopyroxene crystallization. At $\sim 800 \mathrm{MPa}$, the authors found that clinopyroxene saturation occurred at $1120-1200{ }^{\circ} \mathrm{C}$ and $1080-1150{ }^{\circ} \mathrm{C}$ for the 2001 and 2006 composition, respectively (Figure 5b). Looking at our experimental data, clinopyroxene is in equilibrium with a trachybasaltic magma when the degree of crystallization is $\leq 13 \mathrm{vol} \%$ (Table 2), otherwise the melt composition would readily evolve towards either basaltic trachyandesite or phonotephrite as a function of $\mathrm{H}_{2} \mathrm{O}$ (Figure 2). The trachybasaltic melts experimentally-derived in this study confirm that the temperatures estimated by Armienti et al. [21] are close to the near-liquidus region of the 2001 and 2006 eruptions. Figure 1 shows that, as the temperature decreases, the near-liquidus surface is controlled by increasing amounts of $\mathrm{H}_{2} \mathrm{O}$. According to this experimental curve, we found that the original $\mathrm{H}_{2} \mathrm{O}$ concentrations in equilibrium with 2001 and 2006 magmas were 3-6 wt \%. Coherently, these $\mathrm{H}_{2} \mathrm{O}$ contents closely match with the hygrometric estimates of 3-6 and 5.5-7 wt \% for 2001 and 2006 eruptions, respectively, reported by Armienti et al. [21] (Figure 5b). With respect to the degassed melt inclusions found at the storage level of $\sim 200 \mathrm{MPa}$ (see also [1]), our experimental data provide quantification for the overall release of $\mathrm{H}_{2} \mathrm{O}(1.5-4 \mathrm{wt} \%)$ that could be expected during impulsive ascent of deep-seated trachybasaltic magmas at Mt. Etna $[4,45,46]$. A migration of volatiles (particularly $\mathrm{H}_{2} \mathrm{O}$ ) transported as supercritical fluids throughout the Etnean plumbing system is also consistent with the early "volatile-induced differentiation model" proposed by Ferlito and Lanzafame [8] and further reappraised by Ferlito [47] to explain the potassium enrichment observed in post-1971 lava flows and the transition from a 
low-density $\mathrm{H}_{2} \mathrm{O}$-melt solution to a high-density melt phase erupted concomitant to a sustained gas flux. Therefore, the huge flux of magmatic gases from depth provides explanation for (1) the low volume of magma erupted in recent years with respect to the great amount of gases measured in the volcanic plume [5,47], (2) the compositions of unusually explosive eruptions fed by primitive, volatile-rich magmas [48], and (3) the textural and compositional variations of plagioclases related to fluid-induced dissolution reactions [9]. In this context, Figure 6 shows that, at $800 \mathrm{MPa}$ and 1070-1090 ${ }^{\circ} \mathrm{C}$, the basaltic trachyandesitic magma is saturated with clinopyroxene when the amount of $\mathrm{H}_{2} \mathrm{O}$ is $5.2-8 \mathrm{wt} \%$. Conversely, at $200-400 \mathrm{MPa}$ and $1050-1070{ }^{\circ} \mathrm{C}$, the $\mathrm{H}_{2} \mathrm{O}$ content decreases to $2.5-4 \mathrm{wt} \%$, implying that at least $50 \%$ of $\mathrm{H}_{2} \mathrm{O}$ is released as a free fluid phase. Both melt inclusion data $[3,43]$ and clinopyroxene-based hygrometric estimates [39,49] confirm that $\mathrm{H}_{2} \mathrm{O}$ degassing starts at $\sim 400 \mathrm{MPa}$, with most of the $\mathrm{H}_{2} \mathrm{O}$ loss occurring at $\mathrm{P}<100 \mathrm{MPa}$.

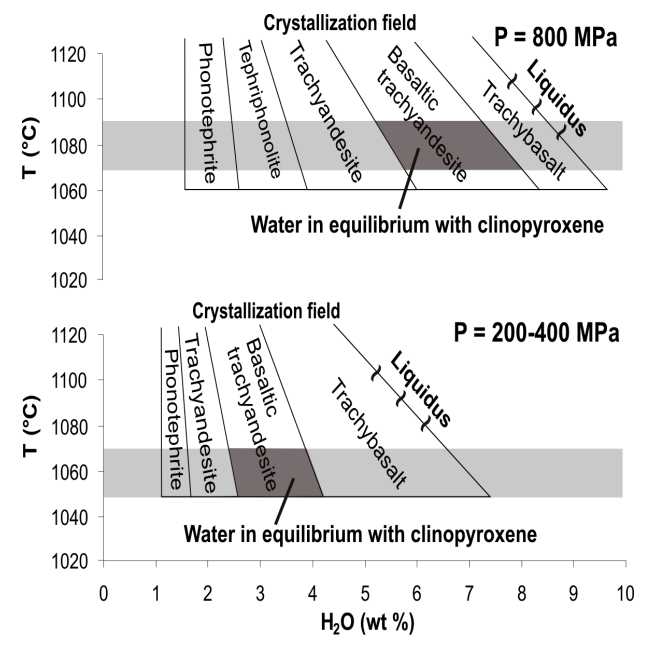

Figure 6. Temperature vs. $\mathrm{H}_{2} \mathrm{O}$ diagram derived using data from hydrous crystallization experiments conducted at high (800 MPa from this study) and moderate (200-400 MPa from literature) pressures. Considering the natural P-T constrains of 2011-2013 lava fountains, the amount of $\mathrm{H}_{2} \mathrm{O}$ in equilibrium with clinopyroxene phenocrysts has been reconstructed. At $800 \mathrm{MPa}$ and $1070-1090{ }^{\circ} \mathrm{C}$, the basaltic trachyandesitic magma is saturated with clinopyroxene when the amount of $\mathrm{H}_{2} \mathrm{O}$ is $5.2-8 \mathrm{wt} \%$. Conversely, at $200-400 \mathrm{MPa}$ and $1050-1070{ }^{\circ} \mathrm{C}$, the $\mathrm{H}_{2} \mathrm{O}$ content decreases to $2.5-4 \mathrm{wt} \%$.

\section{Conclusions}

High-pressure crystallization experiments carried out on a trachybasaltic composition, under $\mathrm{H}_{2} \mathrm{O}$-undersaturated and $\mathrm{H}_{2} \mathrm{O}$-saturated conditions, shed new light on the role $\mathrm{H}_{2} \mathrm{O}$ on the high-pressure crystallization path of magma at Mt. Etna. We found that the crystallization sequence, phase stability, textural and compositional evolution of natural minerals are directly correlated to the transition from $\mathrm{H}_{2} \mathrm{O}$-undersaturated to $\mathrm{H}_{2} \mathrm{O}$-saturated crystallization regimes. Olivine is a late crystallizing phase from $\mathrm{H}_{2} \mathrm{O}$-undersaturated magmas equilibrated at high pressure. In contrast, the clinopyroxene saturation surface is encountered at $800 \mathrm{MPa}$, when the solubility of $\mathrm{H}_{2} \mathrm{O}$ can be very high, ranging from 6 to $8.5 \mathrm{wt} \%$. During upward migration throughout the plumbing system of the volcano, the overall release of $\mathrm{H}_{2} \mathrm{O}$ accompanying clinopyroxene crystallization is constrained between 1.5 and $4 \mathrm{wt} \%$. Therefore, the impulsive ascent of deep-seated trachybasaltic magmas may release a great amount of $\mathrm{H}_{2} \mathrm{O}$. Most of the excess of $\mathrm{H}_{2} \mathrm{O}$ may contribute to the gas emissions from the summit craters and volcano flanks feeding the persistent gas plume at Mt. Etna. However, high-pressure experiments conducted at $\mathrm{H}_{2} \mathrm{O}$-undersaturated conditions cannot account for the distinctly non-equilibrium processes related to the large gas flux that may control magma compositions and trigger eruptions at Mt. Etna volcano. Therefore, further laboratory investigations on decompression and volatile degassing mechanisms may be of help to elucidate magma dynamics related to intense supply of a gas phase $\left(\right.$ mostly $\left._{2} \mathrm{O}\right)$ in the uppermost section of the feeding system. 
Supplementary Materials: The following are available online at http://www.mdpi.com/2075-163X/8/11/482/s1: Table S1. Natural and experimental compositions of Etnean melts; Table S2. MELTS simulations conducted using the HE trachybasalt as starting composition.

Author Contributions: Conceptualization, C.P., S.M. and M.G.; formal analysis, C.P. and S.P.D.C.; investigation, C.P., S.M., M.G. and S.P.D.C.; data curation, C.P.; S.M. and S.P.D.C.; writing-original draft reparation, C.P., S.M., M.G., S.P.D.C., D.M.P., P.S.; writing—review and editing, C.P., S.M., M.G., S.P.D.C., D.M.P., P.S.; visualization, C.P., S.M., M.G., S.P.D.C., D.M.P., P.S.; funding acquisition, M.G., P.S.

Funding: This research received no external funding.

Acknowledgments: We kindly thank M. Serracino for assistance during electron microprobe analysis. Two anonymous reviewers provided instructive and helpful reviews that greatly contributed to the quality of this work.

Conflicts of Interest: The authors declare no conflicts of interest.

\section{References}

1. Corsaro, R.A.; Di Renzo, V.; Distefano, S.; Miraglia, L.; Civetta, L. Relationship between petrologic processes in the plumbing system of Mt. Etna and the dynamics of the eastern flank from 1995 to 2005. J. Volcanol. Geotherm. Res. 2013, 251, 75-89. [CrossRef]

2. Kamenetsky, V.S.; Pompilio, M.; Métrich, N.; Sobolev, A.V.; Kuzmin, D.V.; Thomas, R. Arrival of extremely volatile-rich high-Mg magmas changes explosivity of Mount Etna. Geology 2007, 35, 255-258. [CrossRef]

3. Collins, S.J.; Pyle, D.M.; Maclennan, J. Melt inclusions track pre-eruption storage and dehydratation of magmas at Etna. Geology 2009, 6, 571-574. [CrossRef]

4. Ferlito, C.; Viccaro, M.; Cristofolini, R. Volatile-induced magma differentiation in the plumbing system of Mt. Etna volcano (Italy): Evidence from glass in tephra of the 2001 eruption. Bull. Volcanol. 2008, 70, 455-473. [CrossRef]

5. Ferlito, C.; Coltorti, M.; Lanzafame, G.; Giacomoni, P.P. The volatile flushing triggers eruptions at open conduit volcanoes: Evidence from Mount Etna volcano (Italy). Lithos 2014, 184-187, 447-455. [CrossRef]

6. Bozzano, F.; Gaeta, M.; Lenti, L.; Martino, S.; Paciello, A.; Palladino, D.M.; Sottili, G. Modeling the effects of eruptive and seismic activities on flank instability at Mount Etna, Italy. J. Geophys. Res. Solid Earth 2013, 118, 5252-5273. [CrossRef]

7. Mollo, S.; Scarlato, P.; Lanzafame, G.; Ferlito, C. Deciphering lava flow post-eruption differentiation processes by means of geochemical and isotopic variations: A case study from Mt. Etna volcano. Lithos 2013, 162-163, 115-127. [CrossRef]

8. Ferlito, C.; Lanzafame, G. The role of supercritical fluids in the potassium enrichment of magmas at Mount Etna volcano (Italy). Lithos 2010, 119, 642-650. [CrossRef]

9. Giacomoni, P.P.; Ferlito, C.; Coltorti, M.; Bonadiman, C.; Lanzafame, G. Plagioclase as Archive of Magma Ascent Dynamics on “Open Conduit” Volcanoes: The 2001-2006 Eruptive Period at Mount Etna. Earth Sci. Rev. 2014, 138, 371-393. [CrossRef]

10. Armienti, P.; Tonarini, S.; Innocenti, F.; D'Orazio, M. Mount Etna pyroxene as tracer of petrogenetic processes and dynamics of the feeding system. In Cenozoic Volcanism in the Mediterranean; Beccaluva, L., Bianchini, G., Wilson, M., Eds.; Geological Society of America Special Papers: Boulder, CO, USA, 2007; Volume 418, pp. 265-276.

11. Lanzafame, G.; Mollo, S.; Iezzi, G.; Ferlito, C.; Ventura, G. Unraveling the solidification path of a pahoehoe "cicirara" lava from Mount Etna volcano. Bull. Volcanol. 2013, 75, 703. [CrossRef]

12. Mollo, S.; Giacomoni, P.P.; Coltorti, M.; Ferlito, C.; Iezzi, G.; Scarlato, P. Reconstruction of magmatic variables governing recent Etnean eruptions: Constraints from mineral chemistry and P-T- $f \mathrm{O}_{2}-\mathrm{H}_{2} \mathrm{O}$ modelling. Lithos 2015, 212-215, 311-320. [CrossRef]

13. Mollo, S.; Giacomoni, P.P.; Andronico, D.; Scarlato, P. Clinopyroxene and titanomagnetite cation redistributions at Mt. Etna volcano (Sicily, Italy): Footprints of the final solidification history of lava fountains and lava flows. Chem. Geol. 2015, 406, 45-54. [CrossRef]

14. Métrich, N.; Allard, P.; Spilliaert, N.; Andronico, D.; Burton, M. 2001 flank eruption of the alkali- and volatile-rich primitive basalt responsible for Mount Etna's evolution in the last three decades. Earth Planet. Sci. Lett. 2004, 228, 1-17. [CrossRef] 
15. Dolfi, D.; Trigila, R. Clinopyroxene solid solutions and water in magmas: Results in the system phonolitic tephrite- $\mathrm{H}_{2}$ O. Mineral. Mag. 1983, 47, 347-351. [CrossRef]

16. Metrich, N.; Rutherford, M.J. Low pressure crystallization paths of $\mathrm{H}_{2} \mathrm{O}$-saturated basaltic-hawaitic melts from Mt Etna: Implications for open-system degassing of basaltic volcanoes. Geochim. Cosmochim. Acta 1998, 62, 1195-1205. [CrossRef]

17. Vetere, F.; Mollo, S.; Giacomoni, P.P.; Iezzi, G.; Coltorti, M.; Ferlito, C.; Holtz, F.; Perugini, D.; Scarlato, P. Experimental constraints on the origin of pahoehoe "cicirara" lavas at Mt. Etna Volcano (Sicily, Italy). Bull. Volcanol. 2015, 77, 44. [CrossRef]

18. Hirn, A.; Nicolich, R.; Gallart, J.; Laigle, M.; Cernobori, L.; ETNASEIS Scientific Group. Roots of Etna volcano in faults of great earthquakes. Earth Planet. Sci. Lett. 1997, 148, 171-191. [CrossRef]

19. Duan, X. A general model for predicting the solubility behavior of $\mathrm{H}_{2} \mathrm{O}-\mathrm{CO}_{2}$ fluids in silicate melts over a wide range of pressure, temperature and compositions. Geochim. Cosmochim. Acta 2014, 125, 582-609. [CrossRef]

20. Mitchell, A.L.; Gaetani, G.A.; O'Leary, J.A.; Hairi, E.H. $\mathrm{H}_{2} \mathrm{O}$ solubility in basalt at upper mantle conditions. Contrib. Mineral. Petrol. 2017, 172, 85. [CrossRef]

21. Armienti, P.; Perinelli, C.; Putirka, K.D. A new model to estimate deep-level magma ascent rates, with applications to Mt. Etna (Sicily, Italy). J. Petrol. 2013, 54, 795-813. [CrossRef]

22. Armienti, P.; Clocchiatti, R.; D’Orazio, M.; Innocenti, F.; Petrini, R.; Pompilio, M.; Tonarini, S.; Villari, L. The long-standing 1991-1993 Mount Etna eruption: Petrography and geochemistry of lavas. Acta Vulcanol. 1994, 4, 15-28.

23. Andronico, D.; Corsaro, R.A. Lava fountains during the episodic eruption of South-East Crater (Mt. Etna), 2000: Insights into magma-gas dynamics within the shallow volcano plumbing system. Bull. Volcanol. 2011, 73, 1165-1178. [CrossRef]

24. Viccaro, M.; Giacomoni, P.P.; Ferlito, C.; Cristofolini, R. Dynamics of magma supply at Mt. Etna volcano (Southern Italy) as revealed by textural and compositional features of plagioclase phenocrysts. Lithos 2010, 116, 77-91. [CrossRef]

25. Devine, J.D.; Gardner, J.E.; Brack, H.P.; Laynet, G.D.; Rutherford, M.J. Comparison of microanalytical methods for estimating $\mathrm{H}_{2} \mathrm{O}$ contents of silicic volcanic glasses. Am. Mineral. 1995, 80, 319-328. [CrossRef]

26. Corsaro, R.A.; Pompilio, M. Dynamics of magmas at Mount Etna. In Mt. Etna Volcano Laboratory; Bonaccorso, A., Calvari, S., Coltelli, M., Del Negro, C., Falsaperla, S., Eds.; AGU Geophysical Monograph Series: Washington, DC, USA, 2004; Volume 143, pp. 91-110.

27. Kress, V.G.; Charmichael, I.S.E. The compressibility of silicate liquids containing $\mathrm{Fe}_{2} \mathrm{O}_{3}$ and the effect of composition, temperature, oxygen fugacity and pressure on their redox state. Contrib. Mineral. Petrol. 1991, 108, 82-92. [CrossRef]

28. Toplis, M.J. The thermodynamics of iron and magnesium partitioning between olivine and liquid: Criteria for assessing and predicting equilibrium in natural and experimental systems. Contrib. Mineral. Petrol. 2005, 149, 22-39. [CrossRef]

29. Conte, A.M.; Dolfi, D.; Gaeta, M.; Misiti, V.; Mollo, S.; Perinelli, C. Experimental constraints on evolution of leucite-basanite magma at 1 and $10^{-4} \mathrm{GPa}$ : Implications for parental compositions of Roman high-potassium magmas. Eur. J. Mineral. 2009, 21, 763-782. [CrossRef]

30. Weaver, S.L.; Wallace, P.J.; Johnston, A.D. Experimental constraints on the origins of primitive potassic lavas from the Trans-Mexican Volcanic Belt. Contrib. Mineral. Petrol. 2013, 166, 825-843. [CrossRef]

31. Stormer, J.C.; Nicholls, J. XLFRAC: A program for the interactive testing of magmatic differentiation models. Comput. Geosci. 1978, 4, 143-159. [CrossRef]

32. Lange, R.A.; Carmichael, I.S.E. Densities of $\mathrm{Na}_{2} \mathrm{O}-\mathrm{K}_{2} \mathrm{O}-\mathrm{CaO}-\mathrm{MgO}-\mathrm{FeO}-\mathrm{Fe}_{2} \mathrm{O}_{3}-\mathrm{Al}_{2} \mathrm{O}_{3}-\mathrm{TiO}_{2}-\mathrm{SiO}_{2}$ liquids: New measurements and derived partial molar properties. Geochim. Cosmochim. Acta 1987, 51, 2931-2946. [CrossRef]

33. Mollo, S.; Del Gaudio, P.; Ventura, G.; Iezzi, G.; Scarlato, P. Dependence of clinopyroxene composition on cooling rate in basaltic magmas: Implications for thermobarometry. Lithos 2010, 118, 302-312. [CrossRef]

34. Frey, H.M.; Lange, R.A. Phenocryst complexity in andesites and dacites from the Tequila volcanic field, Mexico: Resolving the effects of degassing vs. magma mixing. Contrib. Mineral. Petrol. 2011, 162, 415-445. [CrossRef] 
35. Putirka, K.D. Thermometers and barometers for volcanic systems. Rev. Mineral. Geochem. 2008, 69, 61-120. [CrossRef]

36. Putirka, K.D.; Mikaelian, H.; Ryerson, F.; Shaw, H. New clinopyroxene-liquid thermobarometers for maric, evolved, and volatile-bearing lava compositions, with applications to lavas from Tibet and the Snake River Plain, Idaho. Am. Mineral. 2003, 88, 1542-1554. [CrossRef]

37. Mollo, S.; Putirka, K.; Iezzi, G.; Scarlato, P. The control of cooling rate on titanomagnetite composition: Implications for a geospeedometry model applicable to alkaline rocks from Mt. Etna volcano. Contrib. Mineral. Petrol. 2013, 165, 457-475. [CrossRef]

38. Mollo, S.; Masotta, M. Optimizing pre-eruptive temperature estimates in thermally and chemically zoned magma chambers. Chem. Geol. 2014, 368, 97-103. [CrossRef]

39. Mollo, S.; Blundy, J.; Scarlato, P.; De Cristofaro, S.P.; Tecchiato, V.; Di Stefano, F.; Vetere, F.; Holtz, F.; Bachmann, $\mathrm{O}$. An integrated $P-T-\mathrm{H}_{2} \mathrm{O}$-lattice strain model to quantify the role of clinopyroxene fractionation on REE $+Y$ and HFSE patterns of mafic alkaline magmas: Application to eruptions at Mt. Etna. Earth Sci. Rev. 2018, 185, 32-56. [CrossRef]

40. Di Carlo, I.; Pichavant, M.; Rotolo, S.G.; Scaillet, B. Experimental Crystallization of a High-K Arc Basalt: The Golden Pumice, Stromboli Volcano (Italy). J. Petrol. 2006, 47, 1317-1343. [CrossRef]

41. Tanguy, J.C.; Condomines, M.; Kieffer, G. Evolution of the Mount Etna magma: Constraints on the present feeding system and eruptive mechanism. J. Volcanol. Geotherm. Res. 1997, 75, 221-250. [CrossRef]

42. Ghiorso, M.S.; Sack, R.O. Chemical mass-transfer in magmatic processes IV. A revised and internally consistent thermodynamic model for the interpolation and extrapolation of liquidus-solid equilibria in magmatic systems at elevated temperatures and pressures. Contrib. Mineral. Petrol. 1995, 119, 197-212. [CrossRef]

43. Spilliaert, N.; Allard, P.; Metrich, N.; Sobolev, A.V. Melt inclusion record of the conditions of ascent, degassing, and extrusion of volatile-rich alkali basalt feeding the powerful 2002 flank eruption of Mount Etna (Italy). J. Geophys. Res. 2006, 111, B04203. [CrossRef]

44. Aiuppa, A.; Federico, C.; Giudice, G.; Gurrieri, S.; Liuzzo, M.; Shinohara, H.; Favara, R.; Valenza, M. Rates of carbon dioxide plume degassing from Mount Etna volcano. J. Geophys. Res. 2006, 111, B09207. [CrossRef]

45. Le Cloarec, M.F.; Pennisi, M. Radionuclides and sulfur content in Mount Etna plume in 1983-1995: New constraints on the magma feeding system. J. Volcanol. Geotherm. Res. 2001, 108, 141-155. [CrossRef]

46. Allard, P.; Behncke, B.; D'Amico, S.; Neri, M.; Gambino, S. Mount Etna 1993-2005: Anatomy of an evolving eruptive cycle. Earth Sci. Rev. 2006, 78, 85-114. [CrossRef]

47. Ferlito, C. Mount Etna volcano (Italy). Just a giant hot spring! Earth Sci. Rev. 2018, 177, 14-23. [CrossRef]

48. Ferlito, C.; Viccaro, M.; Nicotra, E.; Cristofolini, R. Regimes of magma recharge and their control on the eruptive behaviour during the period 2001-2005 at Mt. Etna volcano. Bull. Volcanol. 2012, 74, 533-543. [CrossRef]

49. Perinelli, C.; Mollo, S.; Gaeta, M.; De Cristofaro, S.P.; Palladino, D.M.; Armienti, P.; Scarlato, P.; Putirka, K.D. An improved clinopyroxene-based hygrometer for Etnean magmas and implications for eruption triggering mechanisms. Am. Mineral. 2016, 101, 2774-2777. [CrossRef]

(C) 2018 by the authors. Licensee MDPI, Basel, Switzerland. This article is an open access article distributed under the terms and conditions of the Creative Commons Attribution (CC BY) license (http://creativecommons.org/licenses/by/4.0/). 